University of New Hampshire

University of New Hampshire Scholars' Repository

$12-20-1997$

\title{
Large-scale distributions of tropospheric nitric, formic, and acetic acids over the western Pacific basin during wintertime
}

\author{
R. Talbot \\ University of New Hampshire, robert.talbot@unh.edu \\ Jack E. Dibb \\ University of New Hampshire, jack.dibb@unh.edu \\ Barry Lefer \\ University of Houston - Main \\ Eric Scheuer \\ University of New Hampshire - Main Campus, Eric.Scheuer@unh.edu \\ J D. Bradshaw \\ Georgia Institute of Technology - Main Campus
}

See next page for additional authors

Follow this and additional works at: https://scholars.unh.edu/earthsci_facpub

Part of the Atmospheric Sciences Commons

\section{Recommended Citation}

Talbot, R. W., et al. (1997), Large-scale distributions of tropospheric nitric, formic, and acetic acids over the western Pacific basin during wintertime, J. Geophys. Res., 102(D23), 28303-28313, doi:10.1029/ 96JD02975.

This Article is brought to you for free and open access by the Earth Sciences at University of New Hampshire Scholars' Repository. It has been accepted for inclusion in Earth Sciences Scholarship by an authorized administrator of University of New Hampshire Scholars' Repository. For more information, please contact Scholarly.Communication@unh.edu. 


\section{Authors}

R. Talbot, Jack E. Dibb, Barry Lefer, Eric Scheuer, J D. Bradshaw, S T. Sandholm, S Smyth, D R. Blake, N J. Blake, G W. Sachse, J E. Collins Jr, and G L. Gregory 


\title{
Large-scale distributions of tropospheric nitric, formic, and acetic acids over the western Pacific basin during wintertime
}

\author{
R. W. Talbot ${ }^{1}$, J. E. Dibb ${ }^{1}$, B. L. Lefer ${ }^{1}$, E. M. Scheuer', J. D. Bradshaw ${ }^{2}$, \\ S. T. Sandholm ${ }^{2}$, S. Smyth ${ }^{3}$, D. R. Blake ${ }^{3}$, N. J. Blake, \\ G. W. Sachse ${ }^{4}$, J. E. Collins ${ }^{4}$, and G. L. Gregory ${ }^{4}$
}

\begin{abstract}
We report here measurements of the acidic gases nitric $\left(\mathrm{HNO}_{3}\right)$, formic $(\mathrm{HCOOH})$, and acetic $\left(\mathrm{CH}_{3} \mathrm{COOH}\right)$ over the western Pacific basin during the February-March 1994 Pacific Exploratory Mission-West (PEM-West B). These data were obtained aboard the NASA DC-8 research aircraft as it flew missions in the altitude range of $0.3-12.5 \mathrm{~km}$ over equatorial regions near Guam and then further westward encompassing the entire Pacific Rim arc. Aged marine air over the equatorial Pacific generally exhibited mixing ratios of acidic gases $<100$ parts per trillion by volume (pptv). Near the Asian continent, discrete plumes encountered below $6 \mathrm{~km}$ altitude contained up to 8 parts per billion by volume (ppbv) $\mathrm{HNO}_{3}$ and 10 ppbv $\mathrm{HCOOH}$ and $\mathrm{CH}_{3} \mathrm{COOH}$. Overall there was a general correlation between mixing ratios of acidic gases with those of $\mathrm{CO}$, $\mathrm{C}_{2} \mathrm{H}_{2}$, and $\mathrm{C}_{2} \mathrm{Cl}_{4}$, indicative of emissions from combustion and industrial sources. The latitudinal distributions of $\mathrm{HNO}_{3}$ and $\mathrm{CO}$ showed that the largest mixing ratios were centered around $15^{\circ} \mathrm{N}$, while $\mathrm{HCOOH}, \mathrm{CH}_{3} \mathrm{COOH}$, and $\mathrm{C}_{2} \mathrm{Cl}_{4}$ peaked at $25^{\circ} \mathrm{N}$. The mixing ratios of $\mathrm{HCOOH}$ and $\mathrm{CH}_{3} \mathrm{COOH}$ were highly correlated $\left(r^{2}=0.87\right)$ below $6 \mathrm{~km}$ altitude, with a slope $(0.89)$ characteristic of the nongrowing season at midlatitudes in the northern hemisphere. Above $6 \mathrm{~km}$ altitude, $\mathrm{HCOOH}$ and $\mathrm{CH}_{3} \mathrm{COOH}$ were marginally correlated $\left(r^{2}=0.50\right)$, and plumes well defined by $\mathrm{CO}, \mathrm{C}_{2} \mathrm{H}_{2}$, and $\mathrm{C}_{2} \mathrm{Cl}_{4}$ were depleted in acidic gases, most likely due to scavenging during vertical transport of air masses through convective cloud systems over the Asian continent. In stratospheric air masses, $\mathrm{HNO}_{3}$ mixing ratios were several parts per billion by volume (ppbv), yielding relationships with $\mathrm{O}_{3}$ and $\mathrm{N}_{2} \mathrm{O}$ consistent with those previously reported for $\mathrm{NO}_{y}$.
\end{abstract}

\section{Introduction}

Acidic gases are important trace participants in photochemical and heterogeneous processes occurring in the Earth's troposphere. The principal acidic gases of interest are sulfuric $\left(\mathrm{H}_{2} \mathrm{SO}_{4}\right)$, hydrochloric $(\mathrm{HCl})$, nitric $\left(\mathrm{HNO}_{3}\right)$, and the monocarboxylics formic $(\mathrm{HCOOH})$ and acetic $\left(\mathrm{CH}_{3} \mathrm{COOH}\right)$. Our focus here is on the latter three, which we measured over the western Pacific Ocean during the NASA Pacific Exploratory Mission - West (PEM-West B) in February-March 1994.

Measurements of acidic gases in the troposphere over the western Pacific basin are scarce. Mixing ratios of $\mathrm{HNO}_{3}$ and aerosol $\mathrm{NO}_{3}^{-}$were surveyed over the basin's equatorial and southern (to $24^{\circ} \mathrm{S}$ ) portions during the Global Atmospheric Measurements Experiment on Tropospheric Aerosols and Gases (GAMETAG) in the late 1970s [Huebert and Lazrus, 1980]. There was no latitudinal trend in the mixing ratio of $\mathrm{HNO}_{3}$, with a median value of 120 parts per trillion by volume (pptv) observed. Mixing ratios ranged from $<30$ to $540 \mathrm{pptv}$ in the free troposphere, and the molar ratio of $\mathrm{HNO}_{3} / \mathrm{NO}_{3}^{-}$generally ranged from 3 to 5 . This situation was

\footnotetext{
'Institute for the Study of Earth Oceans and Space, University of New Hampshire, Durham

${ }^{2}$ School of Earth and Atmospheric Sciences, Georgia Institute of Technology, Atlanta.

${ }^{3}$ Department of Chemistry, University of California, Irvine.

${ }^{4}$ NASA Langley Research Center, Hampton, Virginia.

Copyright 1997 by the American Geophysical Union

Paper number 96JD02975.

0148-0227/97/96JD-02975\$09.00
}

reversed in the marine boundary layer with values of this ratio always less than 1.0, presumably due to uptake of $\mathrm{HNO}_{3}$ vapor onto sea-salt aerosols [Huebert and Lazrus, 1978].

Shipboard measurements of the mixing ratios of $\mathrm{HNO}_{3}$ and aerosol $\mathrm{NO}_{3}^{-}$in the equatorial Pacific marine boundary layer generally agree with the GAMETAG results, but the values were somewhat lower [Huebert, 1980]. The average mixing ratio of $\mathrm{HNO}_{3}$ was 38 pptv, while aerosol $\mathrm{NO}_{3}{ }^{-}$was typically several times greater than this. Again no latitudinal gradients were found from $7^{\circ} \mathrm{N}$ to $9^{\circ} \mathrm{S}$.

Nitric acid vapor and aerosol $\mathrm{NO}_{3}{ }^{-}$have also been measured at the Mauna Loa Observatory (MLO), Hawaii, and between this site and the western United States from aircraft during the NASA Chemical Instrumentation Intercomparison Test and Evaluation (CITE 2) [Galasyn et al., 1987; Huebert et al., 1990; Norton, 1992; Lee et al., 1994]. These studies revealed that in this region of the Pacific basin the mixing ratios of $\mathrm{HNO}_{3}$ and aerosol $\mathrm{NO}_{3}^{-}$are commonly less than $100 \mathrm{pptv}$ and $50 \mathrm{pptv}$, respectively, except during short events where air masses with apparent continental influences were sampled.

Carboxylic acids were measured from shipboard platform over the western Pacific in April-July 1987 [Arlander et al., 1990]. The average mixing ratios of $\mathrm{HCOOH}$ and $\mathrm{CH}_{3} \mathrm{COOH}$ were $800 \pm 300$ and $780 \pm 130 \mathrm{pptv}$, respectively, in the northern hemisphere compared to $220 \pm 130$ and $280 \pm 180$ pptv in the southern hemisphere. These marine boundary layer values are similar to those observed during September-October 1991 from an airborne platform in the NASA Pacific Exploratory Mission - West (PEMWest A) [Talbot et al., 1996; Gregory et al., 1996]. Both of these data sets showed that the largest mixing ratios were associated with 
air masses recently influenced ( $<5$ days) by continental emissions. In the free troposphere, mixing ratios were generally twofold less than the average values in the boundary layer air [Talbot et al., 1996; Gregory et al., 1996]. Free tropospheric air masses sampled in May 1988 at the MLO exhibited average mixing ratios of 63 and $94 \mathrm{pptv}$ for $\mathrm{HCOOH}$ and $\mathrm{CH}_{3} \mathrm{COOH}$, respectively [Norton, 1992]. These values are about a factor of 2 smaller than what was observed in aged free tropospheric air over the western Pacific during PEMWest A [Gregory et al., 1996].

The eastward transport of air masses originating over the Asian continent across the northern Pacific basin is well established [Merrill, 1989]. Transport of air mass associated materials peaks in late winter and springtime [Duce et al., 1980; Prospero et al., 1985]. The large high-pressure system that significantly inhibits direct outflow of Asian continental boundary layer air in summer and fall is displaced much farther eastward at other times of the year. Thus it is expected that the PEM-West B data should show a major influence of Asian natural and anthropogenic emissions. An objective of PEM-West B was therefore to sample these emissions using the NASA Ames DC-8 airborne platform and then to assess their impact on atmospheric chemistry over the North Pacific. We present here the large-scale geographic and vertical distributions of $\mathrm{HNO}_{3}, \mathrm{HCOOH}$, and $\mathrm{CH}_{3} \mathrm{COOH}$ observed during the PEM-West $\mathrm{B}$ expedition. Companion papers describe specific aspects of the distribution of acidic gases over the western Pacific basin [Dibb et al., this issue; Talbot et al., this issue].

\section{Experimental Methods}

\subsection{Study Area}

The airborne component of PEM-West B was conducted using the NASA Ames DC-8 research aircraft. Transit and intensive site science missions composed 16 flights, each averaging about 8 hours in duration and covering the altitude range of 0.3 to $12.5 \mathrm{~km}$. The base of operations for these missions progressed from (1) Guam (four missions) to (2) Hong Kong (two missions) and on to (3) Yokota, Japan (four missions). The data used in this paper were obtained in the geographic grid approximately bounded by $0^{\circ}$ $60^{\circ} \mathrm{N}$ latitude and $110^{\circ}-180^{\circ} \mathrm{E}$ longitude. Data obtained on transit flights between these locations was also utilized in this paper. A geographic map of the study region is shown in several companion papers [e.g., Talbot et al., this issue].

The overall scientific rationale and description of individual aircraft missions is described in the PEM-West B overview paper [Hoell et al., this issue]. The features of the large-scale

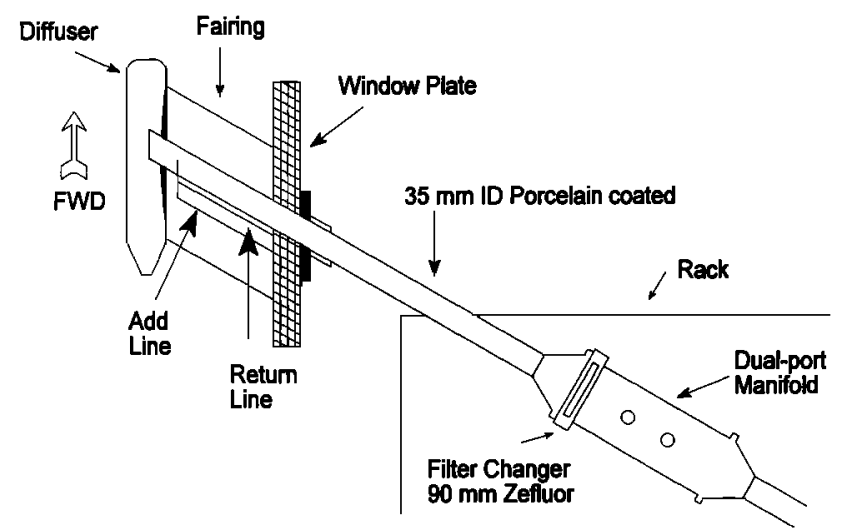

Figure 1. Schematic representation of the manifold used for sampling acidic trace gases aboard the DC-8 aircraft.

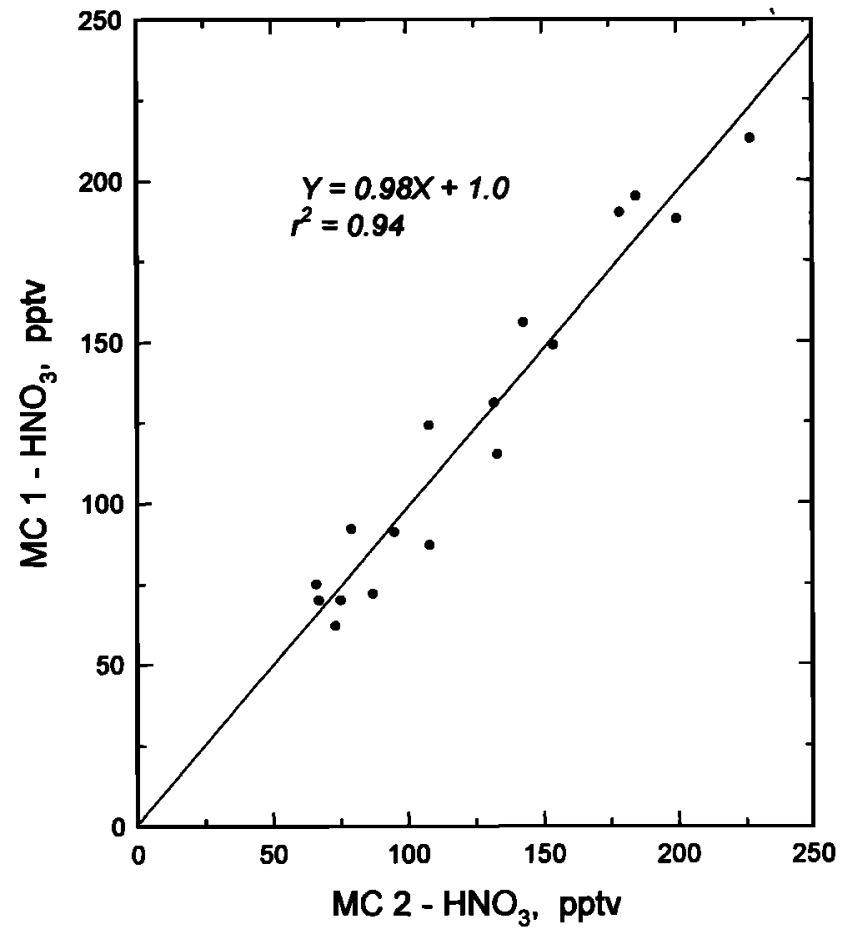

Figure 2. Comparison of atmospheric mixing ratios of $\mathrm{HNO}_{3}$ determined simultaneously with two mist chambers (MC 1 and 2) sampling from the high-flow manifold.

meteorological regime and associated air mass trajectory analyses for the February-March 1994 time period are presented by Merrill et al. [this issue].

\subsection{Sampling and Analytical Methodology}

Acidic gases were subsampled from a constant high-volume $(300$ - 800 liter per minute, LPM) flow of ambient air using the mist chamber technique [Talbot et al., 1988, 1990]. Sample collection intervals were typically $10 \mathrm{~min}$. The inlet manifold consisted of a $1.3 \mathrm{~m}$ length of $35 \mathrm{~mm}$ ID porcelain coated steel pipe (Figure 1). The pipe extended from the DC-8 fuselage to provide a $90^{\circ}$ orientation to the ambient air streamline flow. To facilitate pumping of the high-volume manifold flow, a diffuser was mounted over the end of the inlet pipe parallel to the DC-8 fuselage. The diffuser was "torpedo shaped," having a forward opening of $80 \mathrm{~mm}$ and $55 \mathrm{~mm}$ aft (430 mm in length). This design provided a "shroud" effect by slowing the flow of ambient air through it slightly below the true air speed of the DC-8 and adding a 50 mbar pressurization to the sampling manifold. This eliminated the reverse venturi effect $(\approx 40$ mbar) on the sampling manifold. An additional feature of the diffuser was a curved step around the porcelain manifold which provided the streamline effects of a backward facing inlet. Its function was to facilitate exclusion of aerosol particles greater than $\approx 2 \mu \mathrm{m}$ in diameter from the sampling manifold. Aerosols smaller than this were removed from the sampled airstream using a $1 \mu \mathrm{m}$ pore-sized Zefluor teflon filter that was readily changeable every 5 $10 \mathrm{~min}$. The effectiveness of the shroud in depleting the sampled air stream of large aerosols was examined by sampling in the marine boundary. The manifold prefilter was analyzed for sodium and chloride and these concentrations were compared to those from an aerosol sample collected simultaneously with a forward facing isokinetic probe. These tests showed that the diffuser effectively 


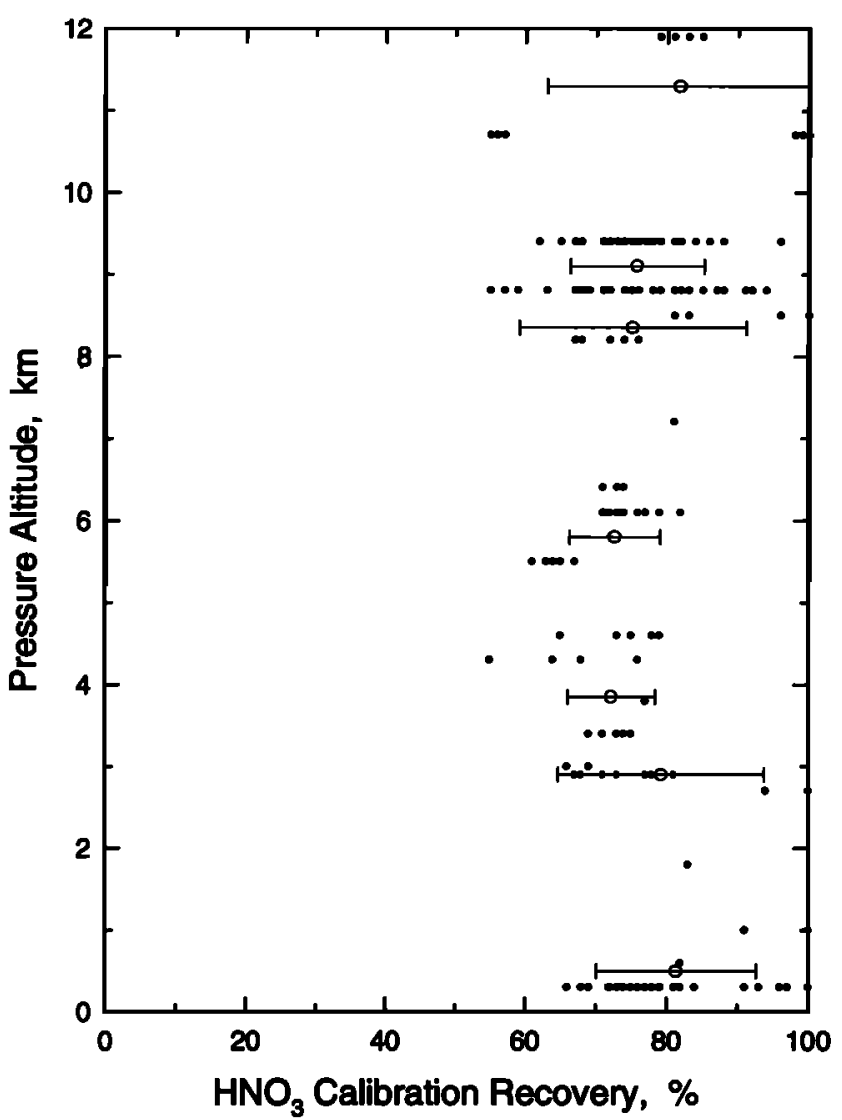

Figure 3a. The passing efficiency of $\mathrm{HNO}_{3}$ through the entire inlet system as a function of altitude $(n=175)$. There does not appear to be a dependence in the recovery on altitude. The open circles represent means, and the bars indicate one standard deviation around this value.

produced an air stream nearly devoid ( $>90 \%$ ) of sea-salt aerosols. Vacuum was applied to the inlet systems using externally mounted high-flow venturis located at an aft station on the DC-8.

In addition to the features described above, the inlet manifold was equipped with the capability for conducting a standard addition of $\mathrm{HNO}_{3}$ into the manifold ambient air stream. This spike was added $\approx 10 \mathrm{~cm}$ downstream inside the manifold pipe through a 6.5 $\mathrm{mm}$ OD teflon tube mounted perpendicular to the air flow. This tube was $\approx 20 \mathrm{~mm}$ long and was maintained at $40^{\circ} \mathrm{C}$ to facilitate passing of calibration gas through it. This design effectively tested the passing efficiency of the entire manifold system.

The calibration system for $\mathrm{HNO}_{3}$ consisted of a permeation oven held at $90^{\circ} \mathrm{C}$ and a single-dilution flow of ultra zero air (1.5 LPM) which swept the oven outflow to either a nylon filter for output quantification or the sampling manifold. The heated teflon tubing through which the $\mathrm{HNO}_{3}$ stream passed was kept equilibrated by a flow design that allowed the calibration gas to constantly pass to near the point of injection into the manifold flow before being dumped aft through a return line (Figure 1). The mixing ratio of $\mathrm{HNO}_{3}$ in the $1.5 \mathrm{LPM}$ flow was typically 200 parts per billion by volume (ppbv). This spike was then diluted several hundred times by the high flow rate of ambient air in the sampling manifold, producing standard additions of $100-1200 \mathrm{pptv}$.

The permeation oven output of $\mathrm{HNO}_{3}$ was monitored on the ground and in the air in near real-time. The permeation source was constant to $\pm 15 \%$ at any given altitude but varied by a factor of 2

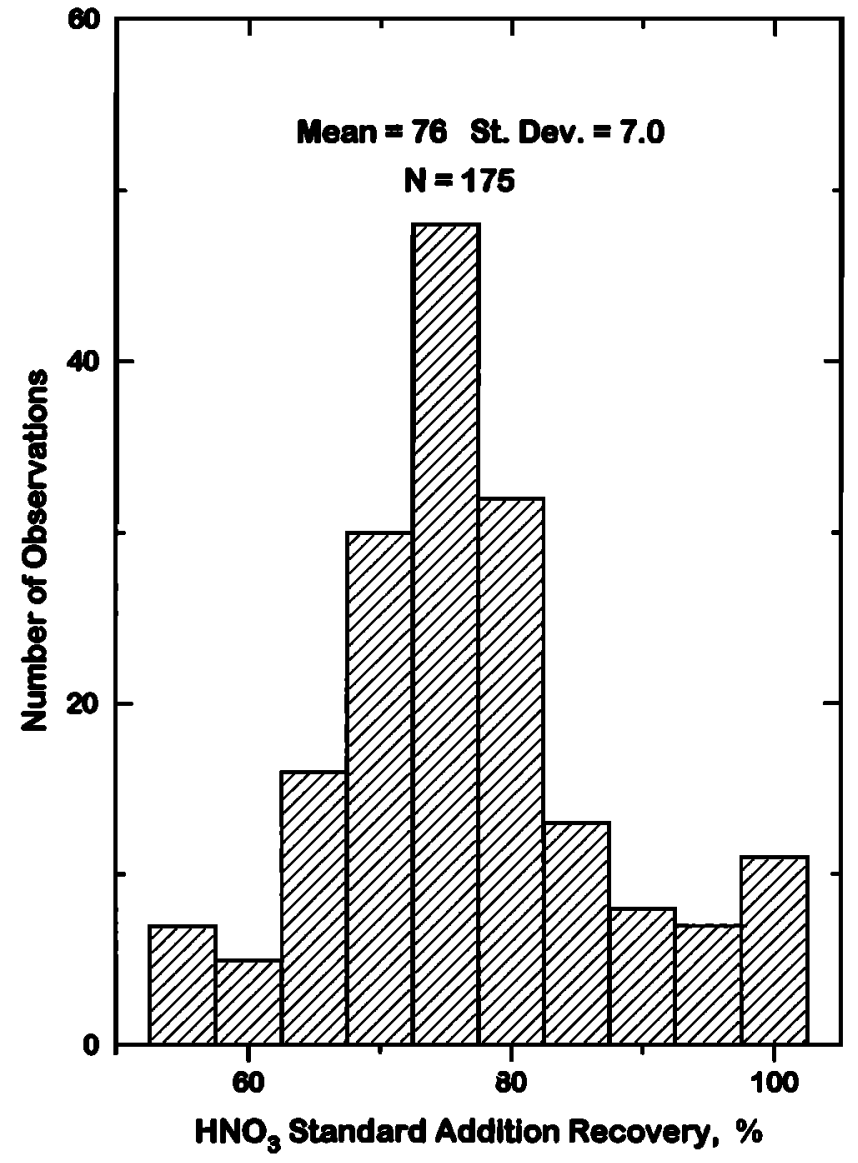

Figure 3b. Summary of passing efficiency tests for $\mathrm{HNO}_{3}$ obtained during PEM-West $\mathrm{B}$. The data are approximately normally distributed with a mean passing efficiency (standard addition recovery) through the entire inlet system of $76 \pm 7 \%(n=175)$.

from ground level to $12.5 \mathrm{~km}$ altitude due to lack of sophisticated pressure control in this preliminary version of a calibration system. The operating characteristics of the calibration system were satisfactory, however, for a "first-cut" evaluation of the passing efficiency of the sampling inlet.

The concentrations of acidic gases were quantified using a custom built dual ion chromatography system equipped a with computer interface for data acquisition. The system was composed primarily of Dionex components with the detectors and flow system thermostated to $40^{\circ} \mathrm{C}$. Eluants were constantly purged with He gas. Nitric acid was measured using a fast anion column, while the carboxylic acids were determined using an AS4 column. Concentrator columns and electronic suppression was used in both chromatography systems. Calibration curves generated on the ground and in the air agreed within $\pm 2 \%$. We thus were able to determine atmospheric mixing ratios of acidic gases in near realtime.

In addition to data for acidic gases, we present selected information on several important trace gases including ozone $\left(\mathrm{O}_{3}\right)$, carbon monoxide $(\mathrm{CO})$, nitrous oxide $\left(\mathrm{N}_{2} \mathrm{O}\right)$, ethyne $\left(\mathrm{C}_{2} \mathrm{H}_{2}\right)$, and perchloroethylene $\left(\mathrm{C}_{2} \mathrm{Cl}_{4}\right)$. Due to questions regarding the exact suite of compounds being measured by current total reactive nitrogen $\left(\mathrm{NO}_{\mathrm{y}}\right.$ ) instruments (S. Sandholm et al., Comparison of $\mathrm{N}_{x} \mathrm{O}_{y}$ budgets from NASA's ABLE3, PEM-West, and TRACE A measurement programs: An update, submitted to Journal of Geophysical Research, 1996)(hereinafter referred to as Sandholm 

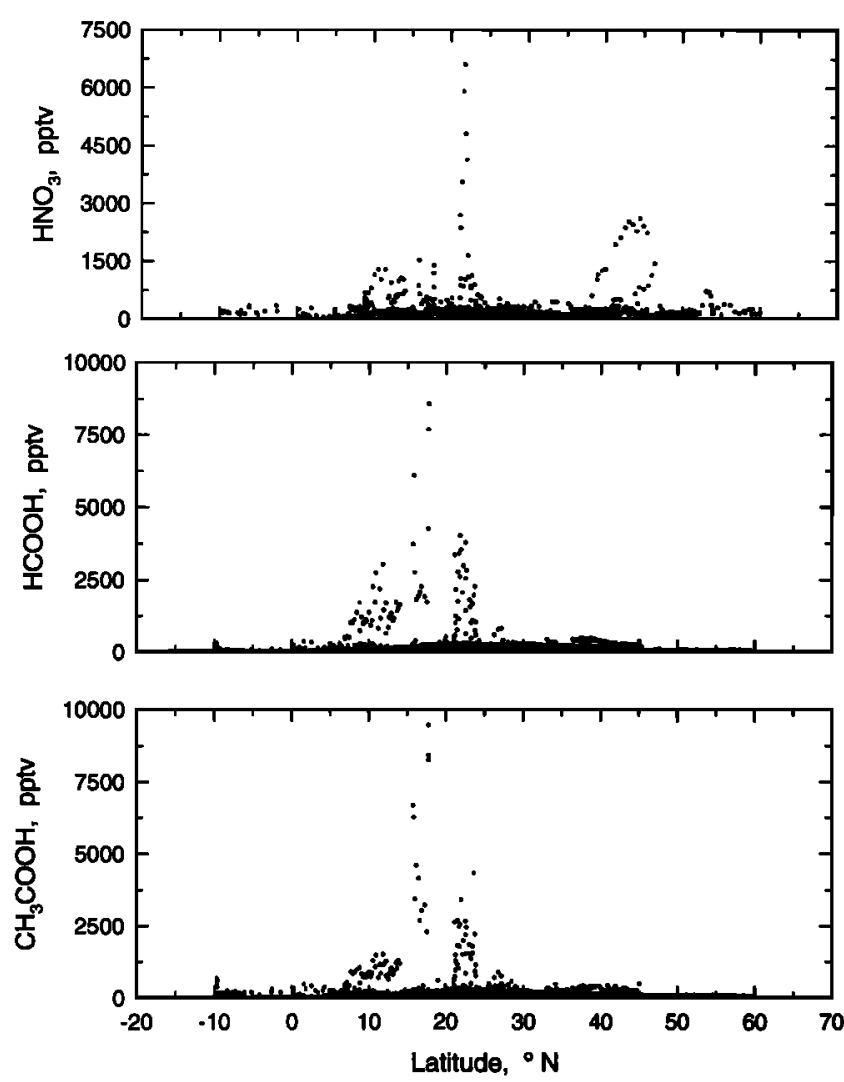

Figure 4a. Latitudinal distribution of the mixing ratios of acidic gases for all measurements performed over the western Pacific Ocean $(n=900)$. The enhancements in the mixing ratios between 5 and $25^{\circ} \mathrm{N}$ reflect the direct advection of pollution plumes off the Asian continent over the North Pacific. The increased mixing ratios of $\mathrm{HNO}_{3}$ surrounding $45^{\circ} \mathrm{N}$ latitude was due to a tropospheric fold encountered over the Sea of Japan during mission 17.

et al., Submitted manuscript, 1996) we use the sum of the speciesspecific measurements to represent $\mathrm{NO}_{y}\left(\Sigma \mathrm{NO}_{y l}=\right.$ nitric oxide [NO] + nitrogen dioxide $\left[\mathrm{NO}_{2}\right]+\mathrm{HNO}_{3}+$ peroxyacetylnitrate $[\mathrm{PAN}]+$ aerosol nitrate $\left[\mathrm{NO}_{3}{ }^{-}\right]$). Since $\mathrm{NO}_{2}$ was not measured during PEMWest $\mathrm{B}$, its mixing ratio was calculated using a one-dimensional time dependent photochemical model [Crawford et al., 1996]. Aerosol $\mathrm{NO}_{3}^{-}$was measured on bulk filter samples collected with a forward facing isokinectic probe housed in a shroud to ensure isoaxial flow [Dibb et al., 1996]. Ninety millimeter diameter $2 \mu \mathrm{m}$ pore sized Zefluor teflon filters were used as the collection substrate. Specific details regarding the measurement of various other species used in this paper are presented in companion papers [Blake et al., this issue; Sandholm et al., this issue]. The measurements of these species were averaged to provide mean values that corresponded directly to the acidic gas sampling times. This merged data product was generated at the Georgia Institute of Technology, and it is used exclusively in this paper.

\section{Results of $\mathrm{HNO}_{3}$ Instrument Tests}

To assess the measurement precision of acidic gases, we conducted simultaneous sampling with two mist chambers during three flights out of Guam. These data were obtained in aged free tropospheric air of relatively uniform composition (e.g., CO $75 \pm 5$ ppbv). The results of these comparisons for $\mathrm{HNO}_{3}$ are shown in Figure 2. There was excellent agreement in the simultaneously
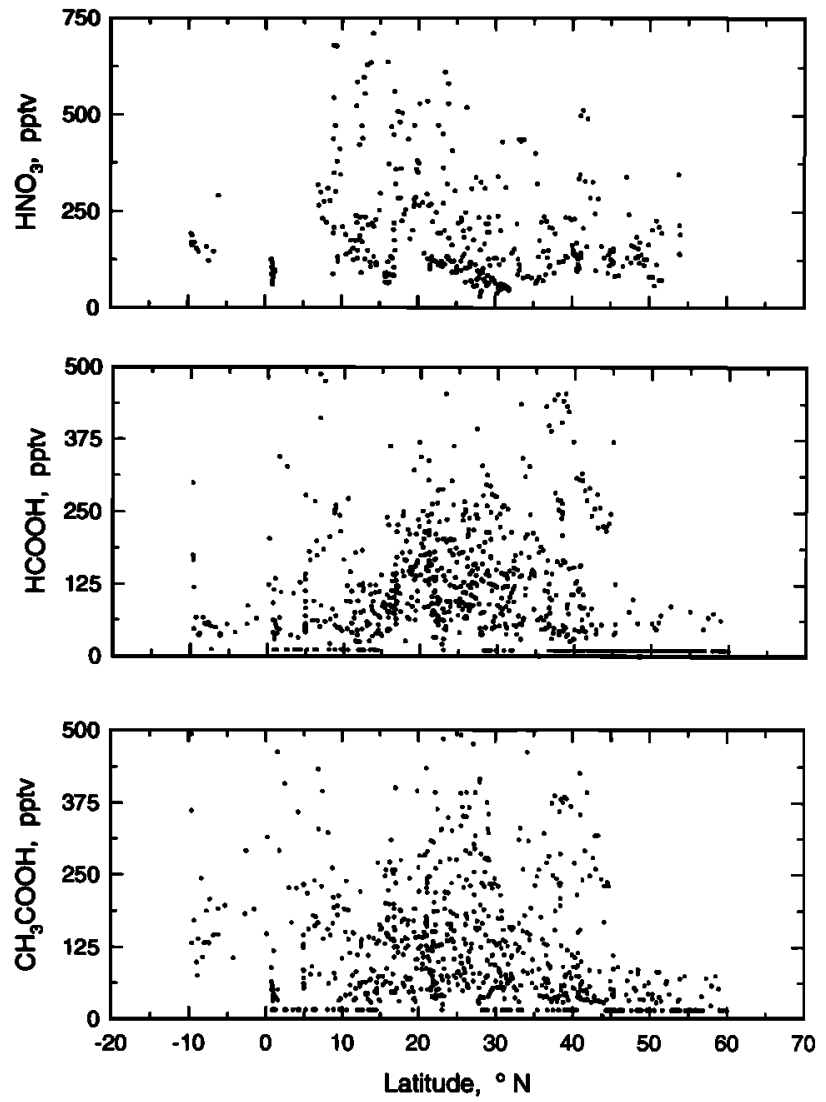

Figure 4b. Same as Figure 4a except for an expanded scale (larger mixing ratios not shown) to show details of data obtained below 6 $\mathrm{km}$ altitude. Notice that at northern latitudes the carboxylic acids were often near or at their limit of detection (i.e., 10 pptv $\mathrm{HCOOH}$ or $15 \mathrm{pptv} \mathrm{CH}_{3} \mathrm{COOH}$ ).

determined mixing ratios of $\mathrm{HNO}_{3}$ over the range of about $50-250$ pptv. The median percent difference, [(MC 1 - MC 2)/MC 1] $\times$ $100 \%$, indicated that the precision of our $\mathrm{HNO}_{3}$ measurements is of the order of $\pm 10 \%$. The precision for $\mathrm{HCOOH}$ and $\mathrm{CH}_{3} \mathrm{COOH}$ was even better than this, averaging $\pm 7 \%$.

On every flight during the PEM-West B expedition, we conducted multiple passing efficiency checks to quantify the transmission of $\mathrm{HNO}_{3}$ through the inlet assembly. These tests were conducted on level flight legs by making several ambient measurements that bracketed in time standard additions into the same airstream. This allowed us to have reasonable confidence in the ambient air substraction to determine the spike recovery. In some cases the ambient variability was too large $(> \pm 30 \%)$ to make a meaningful assessment of the passing efficiency. These data were discarded, leaving 175 data points for evaluation purposes. As shown in Figure $3 \mathrm{a}$, these tests were conducted over the entire operating range of the DC-8 aircraft, from 0.3 to $12 \mathrm{~km}$. The mean passing efficiency was $76 \pm 7 \%$ (Figure $3 \mathrm{~b}$ ), with no apparent dependence on altitude. Although the initial $10 \mathrm{~cm}$ of the manifold was not included in the passing efficiency tests, this represents only $8 \%$ of its total length. It is unlikely that significant loss of $\mathrm{HNO}_{3}$ occurred in this initial section of the manifold. Our experience in passing $\mathrm{HNO}_{3}$ through tubing indicates that most of the wall losses occur in the last half of the flow path.

Great effort was placed on performing passing efficiency tests as close to ambient $\mathrm{HNO}_{3}$ mixing ratios as possible. The standard 

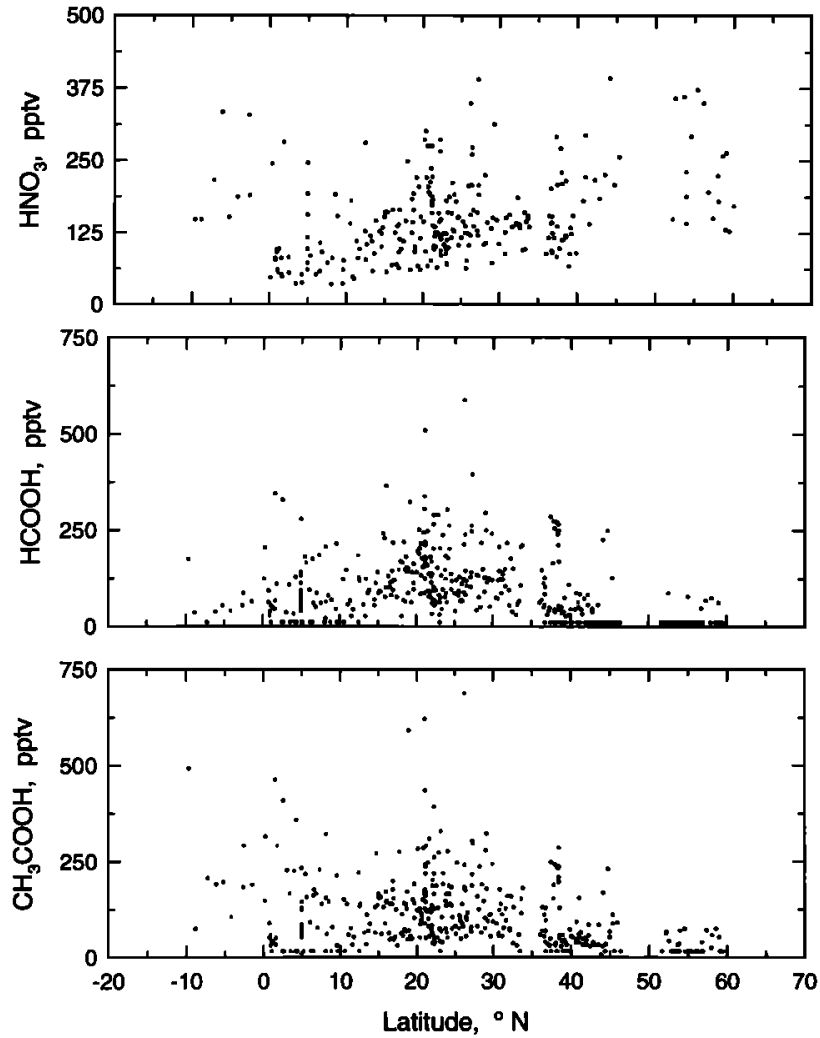

Figure 4c. Same as Figure 4a except for an expanded scale (larger mixing ratios not shown) to show details of data obtained above 6 $\mathrm{km}$ altitude. The apparent increase in the mean value of the $\mathrm{HNO}_{3}$ mixing ratio with northerly latitude is probably driven by inputs of stratospheric air masses during tropospheric folds.

additions were thus conducted at mixing ratios of $50-100 \%$ above the ambient ones. Spikes performed in the few-ppbv range always yielded passing efficiencies of $100 \pm 10 \%$ (not shown). Our experience indicates that it is essential to conduct standard additions for $\mathrm{HNO}_{3}$ at near-ambient levels to meaningfully test the measurement system.

The $\mathrm{HNO}_{3}$ data presented in this paper have not been corrected for passing efficiency. This decision was based on the uncertainties associated with the permeation oven output and background subtraction. Improvements to maintain precise flow and pressure control in our calibration system plus an increase in the measurement time resolution should rectify these problems in the future. Based on the passing efficiency tests and other potential errors in the sampling and analysis, the overall uncertainty of the $\mathrm{HNO}_{3}$ measurements is estimated to be $\pm 35 \%$. The limit of detection is 5 pptv for a 15 -min sampling interval. Extensive ground-based tests for $\mathrm{HCOOH}$ and $\mathrm{CH}_{3} \mathrm{COOH}$ indicate that (1) their passing efficiency through our inlet is $>90 \%$, (2) the overall measurement uncertainty for these species is \pm 20 and $25 \%$ and, (3) their limits of detection for a 15-min sampling period are 10 and 15 pptv, respectively. Our experience indicates that these carboxylic acid species are significantly less prone to wall loss problems than $\mathrm{HNO}_{3}$.

\section{Distribution of Acidic Gases Over the Western Pacific Basin}

The latitudinal distribution of acidic gases over the western Pacific basin is shown in Figure 4a. These data $(n \approx 900)$ encompass the $0.3-12 \mathrm{~km}$ altitude range. Subsets of the data presented in
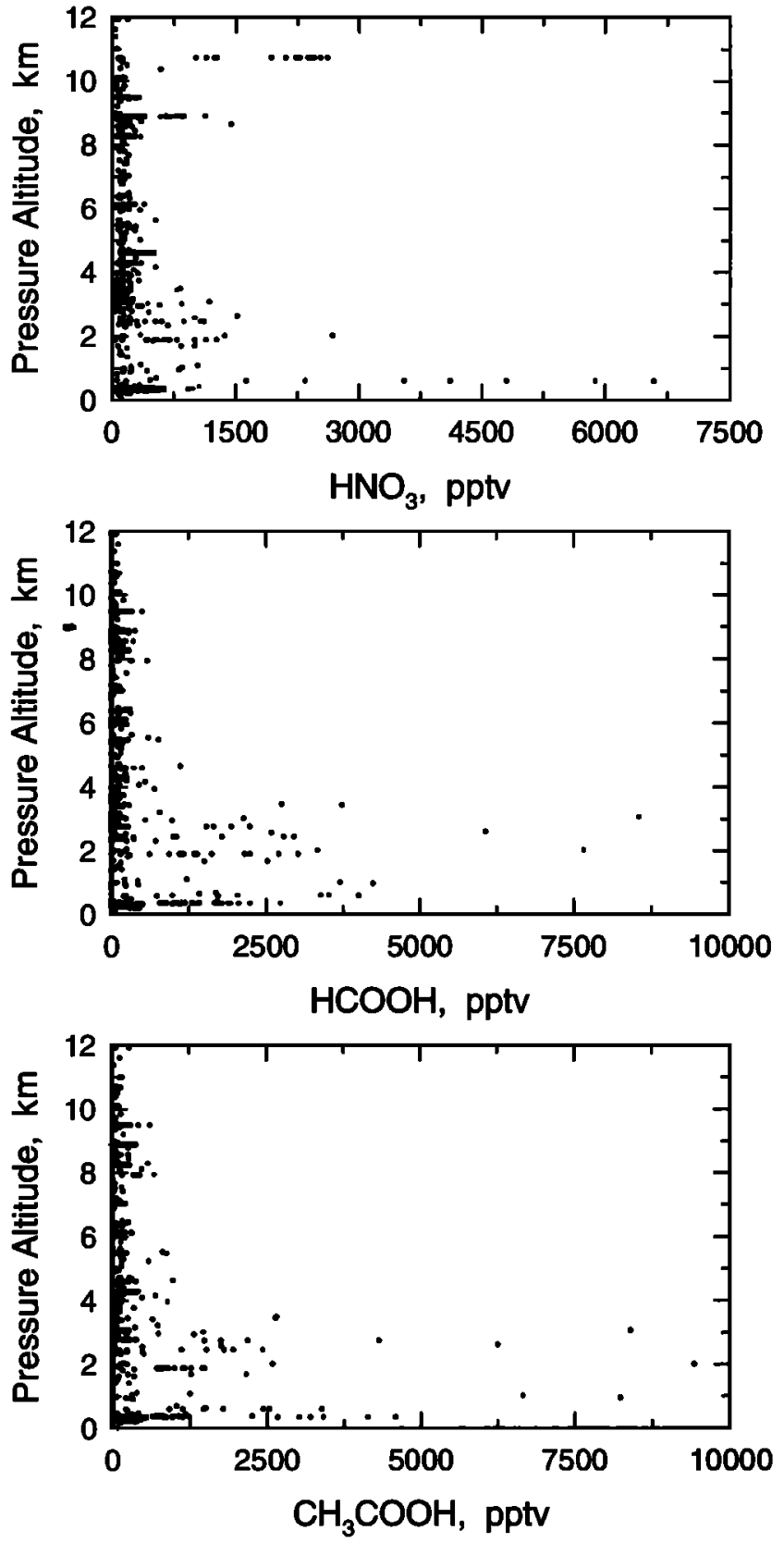

Figure 5. Vertical distribution of the mixing ratios of acidic gases for all measurements performed over the western Pacific Ocean ( $n$ $=900$ ). The enhanced mixing ratios of $\mathrm{HNO}_{3}$ at 9 and $11 \mathrm{~km}$ reflect measurements during tropospheric folds. These data indicate that Asian continental outflow of acidic gases was primarily confined to altitudes below $6 \mathrm{~km}$.

Figure $4 \mathrm{a}$ are shown in Figures $4 \mathrm{~b}$ and $4 \mathrm{c}$ on an expanded (mixing ratio) scale cropped to remove the upper $5 \%$ of the values. The data depicted in Figures $4 \mathrm{~b}$ and $4 \mathrm{c}$ are for the altitudes bands $0-5.9 \mathrm{~km}$ and $6-12 \mathrm{~km}$ respectively. This break in the vertical distribution was based on the fact that the majority of the continental outflow occurred below $6 \mathrm{~km}$ altitude (Figure 5).

In a companion paper, we developed an air mass classification scheme for the PEM-West B data based on backward isentropic trajectories and their associated transit time from the Asian continent [Talbot et al., this issue; Merrill et al., this issue]. This analysis showed that the majority of the PEM-West B data reflect 

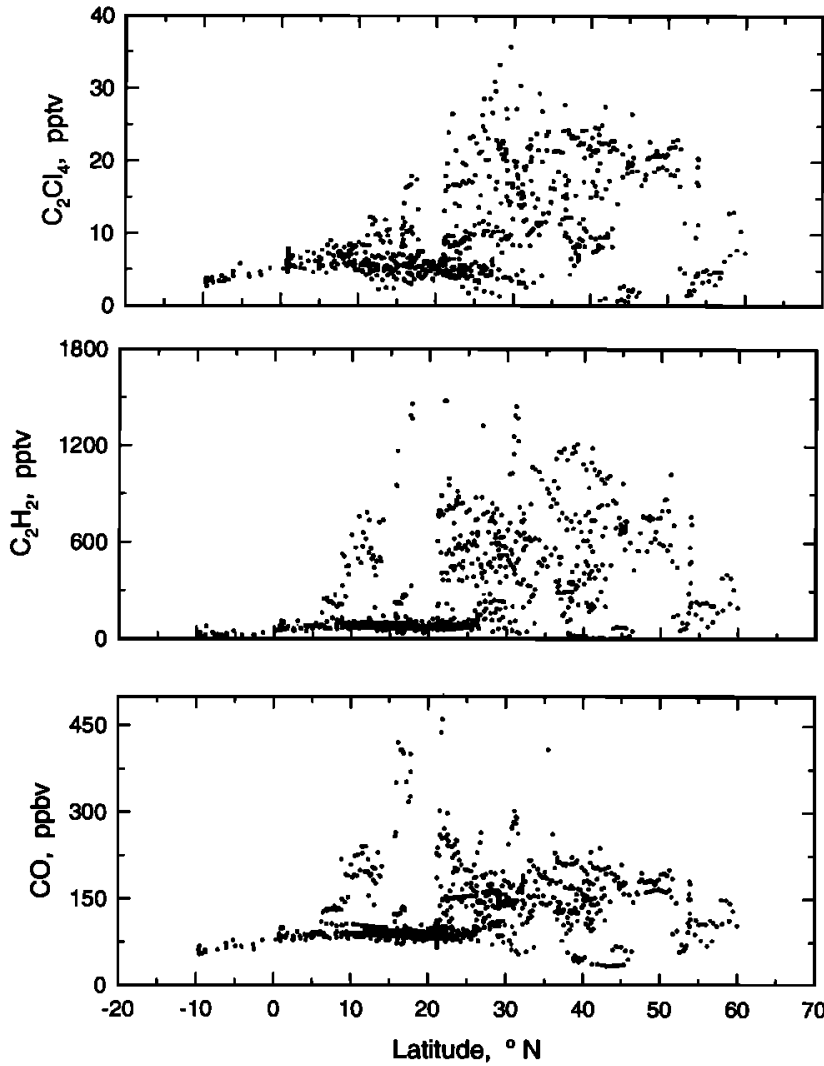

Figure 6. Latitudinal distribution of the mixing ratios of $\mathrm{CO}, \mathrm{C}_{2} \mathrm{H}_{2}$, and $\mathrm{C}_{2} \mathrm{Cl}_{4}$ over the western Pacific basin during PEM-West $\mathrm{B}$.

rapid advection ( $<2$ days) of air masses from over the Asian continent to the western Pacific troposphere.

The principal outflow of acidic gases from the Asian continent was concentrated in the $5-25^{\circ} \mathrm{N}$ latitude band (Figure 4a). The enhanced mixing ratios of $\mathrm{HNO}_{3}$ near $40^{\circ} \mathrm{N}$ were observed during a tropospheric fold over the Sea Japan (see section 5). Thus the discrete continental plumes containing highly elevated mixing ratios of acidic gases that were observed leaving the Asian continent were not evident near Japan $\left(30-40^{\circ} \mathrm{N}\right)$. In fact, most of the air masses sampled east of Japan were apparently influenced by precipitation scavenging [Talbot et al., this issue]. During PEM-West B, mixing ratios as large as $7 \mathrm{ppbv} \mathrm{HNO}_{3}$ and $10 \mathrm{ppbv} \mathrm{HCOOH}$ and $\mathrm{CH}_{3} \mathrm{COOH}$ were observed within $250 \mathrm{~km}$ eastward from the Asian continent. In contrast, the mixing ratios in this same region during PEM-West A did not exceed 500 pptv for $\mathrm{HNO}_{3}$ and 1000 pptv for $\mathrm{HCOOH}$ or $\mathrm{CH}_{3} \mathrm{COOH}$ [Talbot et al., 1996].

A significant component of the material outflow from the Pacific rim region appears to originate from anthropogenic combustion activities. Evidence for this source is derived from $\mathrm{C}_{2} \mathrm{Cl}_{4}, \mathrm{C}_{2} \mathrm{H}_{2}$, and $\mathrm{CO}$ (Figure 6). While $\mathrm{CO}$ is a general indicator of combustion emissions [Warneck, 1988], this is the only known source of $\mathrm{C}_{2} \mathrm{H}_{2}$ [Singh and Zimmerman, 1992]. $\mathrm{C}_{2} \mathrm{Cl}_{4}$ is released exclusively by industrial processes [Blake et al., 1996]. Although we did not identify exceedingly strong correlations $\left(r^{2}>0.7\right)$ between acidic gases and other species, the similarity in their latitudinal trends with combustion tracers is clearly apparent (Figures 3a and 5). This same lack of high correlation between carboxylic acids and other atmospheric species has been observed in free tropospheric air at Mauna Loa, Hawaii [Norton, 1992], and in boundary layer air over the eastern United States [Talbot et al., 1995].
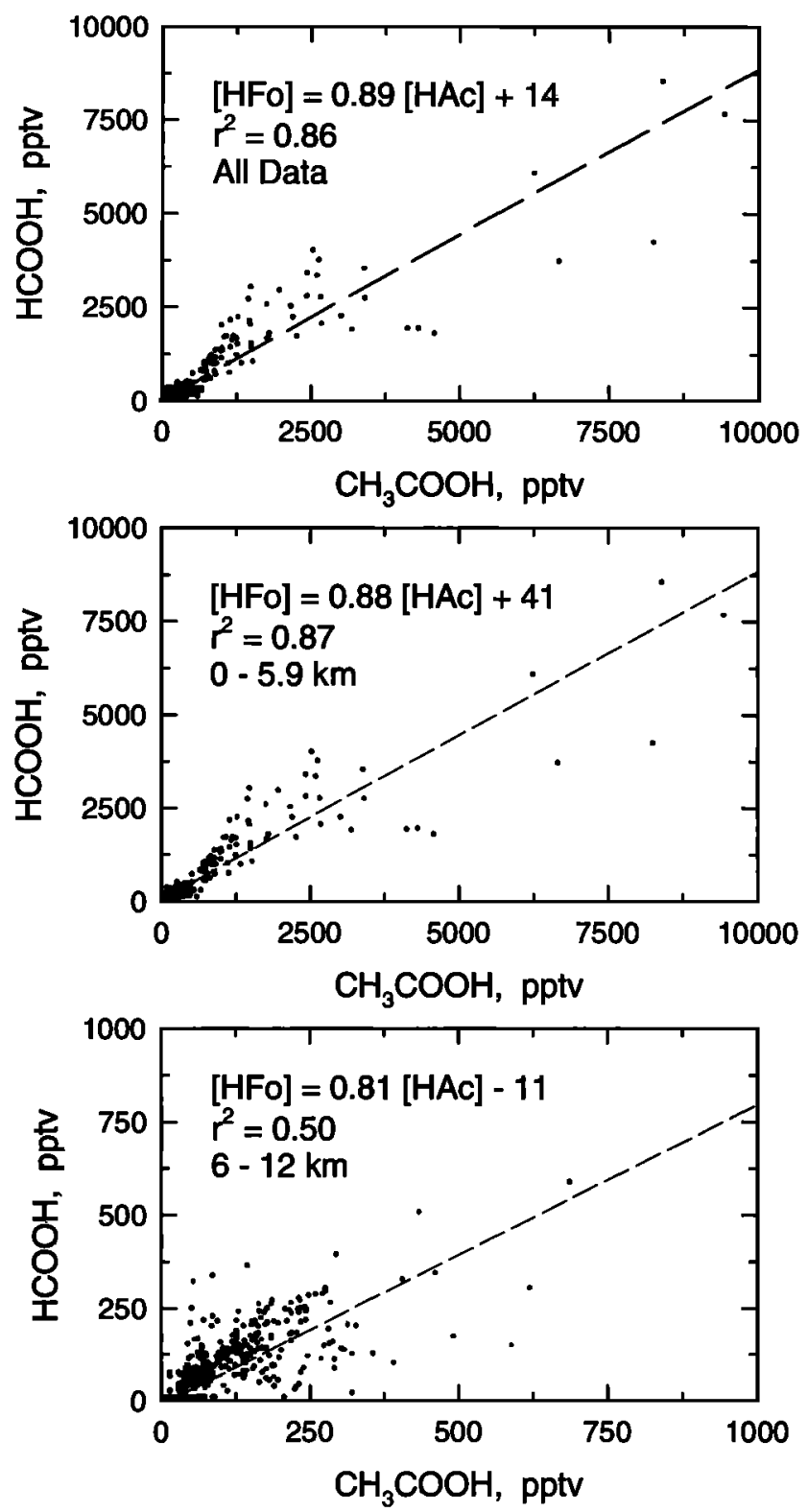

Figure 7. Relationship between mixing ratios of $\mathrm{HCOOH}$ and $\mathrm{CH}_{3} \mathrm{COOH}$. The correlation was much stronger in air masses directly outflowing from the Asian continent (i.e., $<6 \mathrm{~km}$ altitude).

Peak mixing ratios of $\mathrm{HNO}_{3}$ exclusive of individual plumes were centered around $15^{\circ} \mathrm{N}$ latitude (Figure $4 \mathrm{~b}$ ), similar to those of $\mathrm{CO}$ (Figure 6). This correlation and the absence of a coincident one with $\mathrm{C}_{2} \mathrm{Cl}_{4}$ points to nonindustrial sources (e.g., space heating, cooking, or vehicle emissions) as the potentially dominate emissions contributor in this area. During the growing season, $\mathrm{HCOOH}$ and $\mathrm{CH}_{3} \mathrm{COOH}$ probably have dominate sources from biogenic emissions [Talbot et al., 1995]. However, it is likely that anthropogenic sources dominate in wintertime [Talbot et al., 1988]. The apparently synonymous distributions of $\mathrm{HCOOH}$ and $\mathrm{CH}_{3} \mathrm{COOH}$ with $\mathrm{C}_{2} \mathrm{Cl}_{4}$ around $25^{\circ} \mathrm{N}$ latitude is indicative of an industrial pollution source for these species. The falloff in the distributions of $\mathrm{HCOOH}$ and $\mathrm{CH}_{3} \mathrm{COOH}$ at high latitudes compared to that of $\mathrm{C}_{2} \mathrm{Cl}_{4}$ is probably due to wet removal. Indeed, the smaller mixing ratios of $\mathrm{HNO}_{3}$ below $6 \mathrm{~km}$ (Figure $4 \mathrm{~b}$ ) compared to those 


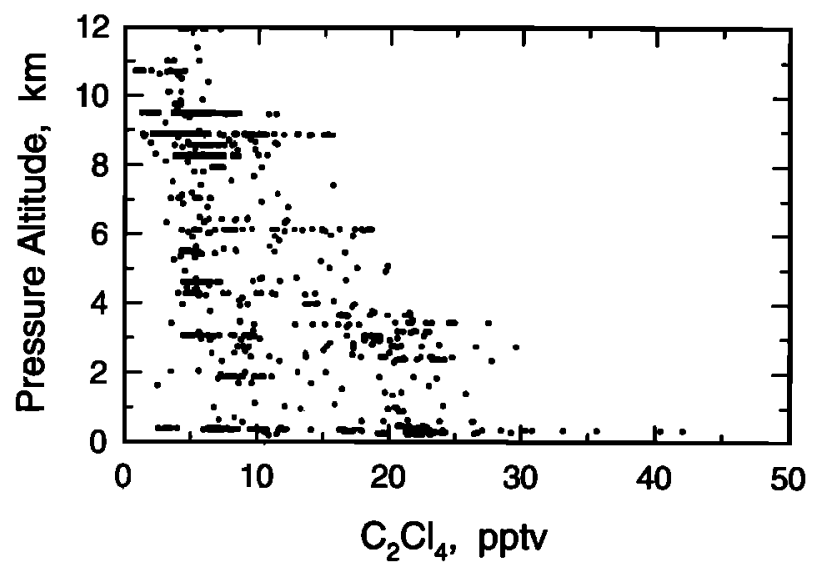

Table 1. Comparison of the Median Mixing Ratios of Acidic Gases During PEM-West A and B

\begin{tabular}{|c|c|c|c|}
\hline & \multicolumn{3}{|c|}{ Altitude } \\
\hline & $<2 \mathrm{~km}$ & $2-7 \mathrm{~km}$ & $7-12 \mathrm{~km}$ \\
\hline \multicolumn{4}{|c|}{ Continental North $<2$ Days } \\
\hline $\mathrm{HNO}_{3}$ & $\begin{array}{l}186 \\
173\end{array}$ & $\begin{array}{r}65 \\
109\end{array}$ & $\begin{array}{r}45 \\
118\end{array}$ \\
\hline $\mathrm{HCOOH}$ & $\begin{array}{l}704 \\
254\end{array}$ & $\begin{array}{l}376 \\
113\end{array}$ & $\begin{array}{l}148 \\
102\end{array}$ \\
\hline $\mathrm{CH}_{3} \mathrm{COOH}$ & $\begin{array}{l}708 \\
264\end{array}$ & $\begin{array}{l}612 \\
113\end{array}$ & $\begin{array}{r}387 \\
95\end{array}$ \\
\hline \multicolumn{4}{|c|}{ Continental South $<2$ Days } \\
\hline $\mathrm{HNO}_{3}$ & $\begin{array}{l}\text { NA } \\
470\end{array}$ & $\begin{array}{r}74 \\
180\end{array}$ & $\begin{array}{r}15 \\
103\end{array}$ \\
\hline $\mathrm{HCOOH}$ & $\begin{array}{r}\text { NA } \\
1153\end{array}$ & $\begin{array}{r}302 \\
48\end{array}$ & $\begin{array}{r}280 \\
91\end{array}$ \\
\hline $\mathrm{CH}_{3} \mathrm{COOH}$ & $\begin{array}{l}\text { NA } \\
866\end{array}$ & $\begin{array}{r}481 \\
43\end{array}$ & $\begin{array}{l}631 \\
117\end{array}$ \\
\hline \multicolumn{4}{|c|}{ Marine $>5$ Days } \\
\hline $\mathrm{HNO}_{3}$ & $\begin{array}{r}20 \\
105\end{array}$ & $\begin{array}{r}10 \\
213\end{array}$ & $\begin{array}{l}10 \\
53\end{array}$ \\
\hline $\mathrm{HCOOH}$ & $\begin{array}{l}90 \\
50\end{array}$ & $\begin{array}{l}45 \\
37\end{array}$ & $\begin{array}{l}45 \\
68\end{array}$ \\
\hline $\mathrm{CH}_{3} \mathrm{COOH}$ & $\begin{array}{r}176 \\
63\end{array}$ & $\begin{array}{r}425 \\
32\end{array}$ & $\begin{array}{r}425 \\
73\end{array}$ \\
\hline
\end{tabular}

First row for each species refers to PEM-West $A$ and the second one to PEM-West $B$. Mixing ratios are stated in pptv. Values for PEM-West A are taken from Talbot et al. [1996] or Gregory et al. [1996] and from Talbot et al. [this issue] for PEM-West B. NA, not available; no data were obtained in this air mass classification during PEM-West $\mathbf{A}$.

plumes sampled at $\geq 6 \mathrm{~km}$ altitude were clearly defined by the $\mathrm{CO}$, $\mathrm{C}_{2} \mathrm{H}_{2}$, and $\mathrm{C}_{2} \mathrm{Cl}_{4}$ distributions. These plumes were conspicuously depleted of acidic gases. Furthermore, above $8 \mathrm{~km}$ altitude there was a high occurrence of methylhydroperoxide/hydrogen peroxide $\left(\mathrm{CH}_{3} \mathrm{OOH} / \mathrm{H}_{2} \mathrm{O}_{2}\right)$ ratio values greater than 1.0 [Talbot et al., this issue], indicative of precipitation influenced air masses [Heikes, 1992]. These observations suggest that the high-altitude plumes represent the affects of vertical convective transport, where soluble species were removed during transport through cloud systems. This vertical transport probably occurred over the Asian continent due to the presence of enhanced mixing ratios of moderately reactive hydrocarbons, nitric oxide (NO), and ${ }^{210} \mathrm{~Pb}$ in these plumes [Blake et al., this issue; Dibb et al., this issue]. Vertical transport of this nature over the Asian continent also appeared to be a prevalent mechanism leading to outflow of polluted air masses during PEMWest A [Dibb et al., 1996; Talbot et al., 1996].

In Table 1 we present a comparison of the median mixing ratios of acidic gases measured during the PEM-West A and B flight programs. These data are divided into three types of air mass classification regimes based on backward isentropic trajectories [Merrill et al., this issue]. The details of this classification scheme are described elsewhere [Talbot et al., 1996, this issue]. Briefly, air masses that passed over the Asian continent or Pacific Rim region less than 2 days ago were divided into two groups: continental north (trajectories originating $>20^{\circ} \mathrm{N}$ ) and continental south (trajectories originating $<20^{\circ} \mathrm{N}$ ). Air masses that had been over the 

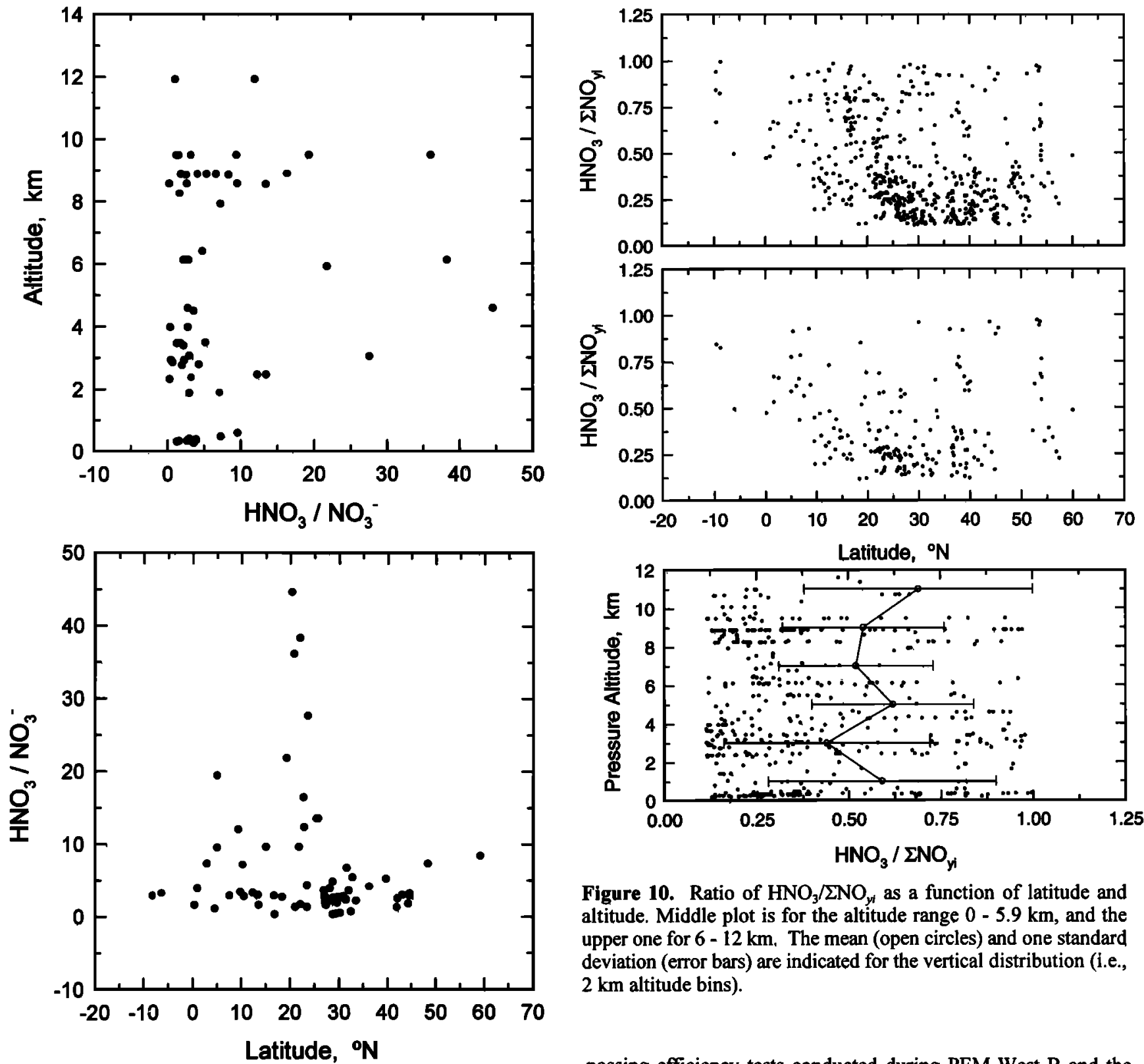

Figure 10. Ratio of $\mathrm{HNO}_{3} / 2 \mathrm{NO}_{y i}$ as a function of latitude and altitude. Middle plot is for the altitude range $0-5.9 \mathrm{~km}$, and the upper one for $6-12 \mathrm{~km}$. The mean (open circles) and one standard deviation (error bars) are indicated for the vertical distribution (i.e., $2 \mathrm{~km}$ altitude bins).

Figure 9. The ratio $\mathrm{HNO}_{3} / \mathrm{NO}_{3}{ }^{-}$as a function of altitude and latitude. The $\mathrm{HNO}_{3}$ data were averaged to correspond to the aerosol $\mathrm{NO}_{3}{ }^{-}$sampling times.

Pacific for at least 5 days are grouped in the marine category.

In general, the carboxylic acids were present at significantly lower mixing ratios during PEM-West B compared to PEM-West A. We believe that this difference reflects the nongrowing season conditions and subsequently reduced natural emissions of $\mathrm{HCOOH}$ and $\mathrm{CH}_{3} \mathrm{COOH}$ during PEM-West B. Evidence for depressed biogenic metabolism processes on the Asian continent is provided by the $2-3 \%$ increase in $\mathrm{CO}_{2}$ mixing ratios during PEM-West $\mathrm{B}$ compared to the PEM-West A study period [Talbot et al., this issue]. The rather enhanced mixing ratio values for the continental south boundary layer during PEM-West B appear to be driven by sampling of anthropogenic emissions from Taiwan [Talbot et al., this issue].

Much larger mixing ratios were observed for $\mathrm{HNO}_{3}$ in PEMWest B compared to PEM-West A. Based on the $\mathrm{HNO}_{3}$ inlet

passing efficiency tests conducted during PEM-West B and the nearly identical instrumental parameters during both PEM-West field campaigns, we have no reason to believe that these differences are measurement related. In fact, in the direct boundary layer outflow from the continental north region $(<2 \mathrm{~km}$ altitude), the median mixing ratios of $\mathrm{HNO}_{3}$ were identical between the two PEM-West field expeditions. In general, however, there appears to have been anomalously low reactive nitrogen (e.g., $\mathrm{NO}_{n}, \mathrm{HNO}_{3}$, and PAN) during PEM-West A compared to other field programs [Sandholm et al., this issue]. The reason for this discrepancy is unclear but it may be related to the sequestering of traditional $\mathrm{NO}_{y}$ species into unknown nitrogen-containing aerosol forms following the eruption of Mount Pinatubo just prior to the PEM-West A field expedition [Sandholm et al., this issue].

The partitioning of atmospheric nitrate between $\mathrm{HNO}_{3}$ vapor and aerosol $\mathrm{NO}_{3}$ - during $\mathrm{PEM}$-West $\mathrm{B}$ favored the gas phase at all times, including in the marine boundary layer (Figure 9). In the $0-5.9 \mathrm{~km}$ altitude range the median value of the ratio $\mathrm{HNO}_{3} / \mathrm{NO}_{3}{ }^{-}$was 2.5 (mean $\pm 1 \sigma=5.7 \pm 8.4$ ), with the largest values observed in pollution plumes. At altitudes of $6-12 \mathrm{~km}$ the ratio increased with a median value of 5.3 (mean $\pm 1 \sigma=8.3 \pm 9.7$ ). Some of the lowest 

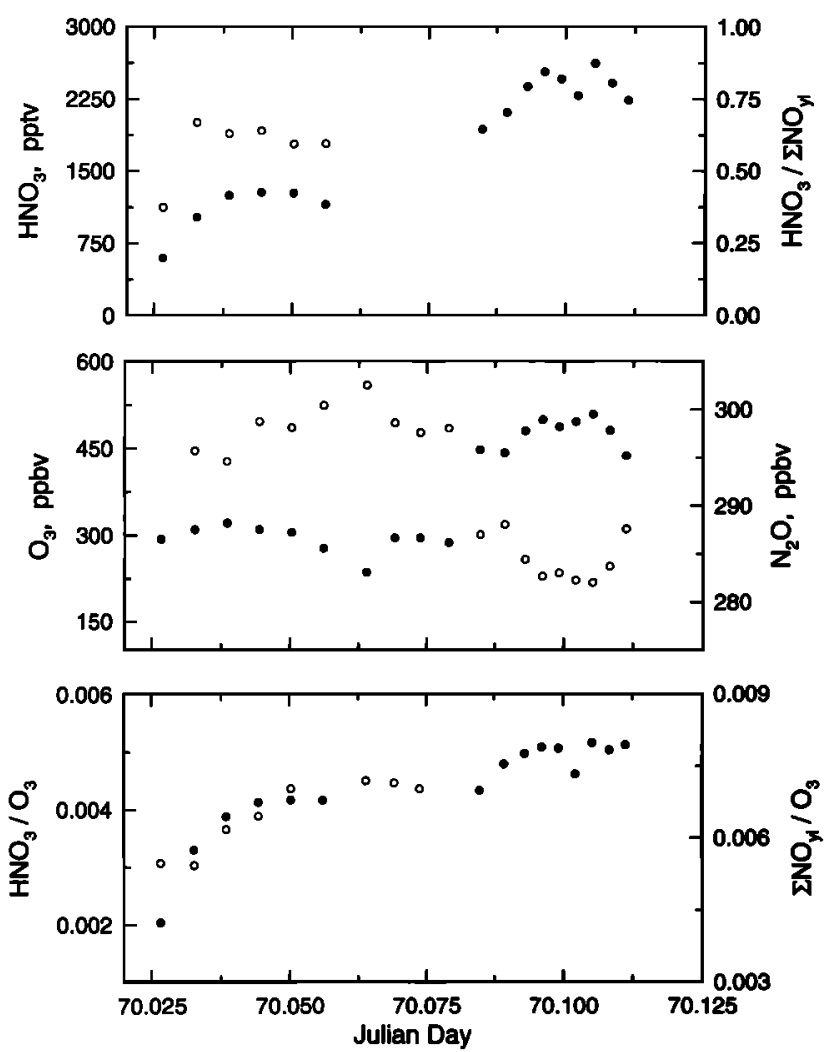

Figure 11. Measurements performed during a tropospheric fold over the Sea of Japan during mission 17. These data were obtained at an altitude of $\approx 11 \mathrm{~km}$. The break in the $\mathrm{HNO}_{3}$ data depict the time interval used for multiple passing efficiency tests. A recovery of $99 \pm 3 \%$ was obtained in this stratospheric air mass. The species on the left axis are indicated by solid circles, while open circles depict species on the right axis.

values of $\mathrm{HNO}_{3} / \mathrm{NO}_{3}^{-}$were found in aged (i.e., air masses that have not passed over continental areas for $>5$ days) marine boundary layer air over the equatorial Pacific where the ratio was typically about 2 [Talbot et al., this issue]. This partitioning is very similar to that observed at various time of the year at Mauna Loa, Hawaii. Galasyn et al. [1987] found boundary layer $\mathrm{HNO}_{3} / \mathrm{NO}_{3}^{-}$ratio values near 3.5, while Norton et al. [1992] observed values of about 2 during May 1988.

To examine the relationship between $\mathrm{HNO}_{3}$ and $\Sigma \mathrm{NO}_{y,}$ the ratio $\mathrm{HNO}_{3} / \Sigma \mathrm{NO}_{y l}$ is shown as a function of latitude and altitude in Figure 10. Due to the heterogeneous nature of the continental outlfow, there was clearly a wide variation in this ratio. However, a few generalities appear to be appropriate. In the boundary layer the $\mathrm{HNO}_{3} / \Sigma \mathrm{NO}_{y}$ ratio tended to exhibit the smallest values near 20 $-30^{\circ} \mathrm{N}$ latitude, averaging 0.25 . In this region there was significant outflow of continental emissions, containing enhanced unoxidized $\Sigma \mathrm{NO}_{y t}$ [Talbot et al., this issue]. In the tropics ( $<10^{\circ}$ latitude), $\mathrm{HNO}_{3}$ was commonly the dominate component of $\Sigma \mathrm{NO}_{y}$, probably due to rapid thermal decomposition of PAN releasing $\mathrm{NO}_{x}$ to subsequently form $\mathrm{HNO}_{3}$ [Wunderli and Gehrig, 1991]. Air masses in low-latitude regions typically exhibit small $\mathrm{PAN} / \mathrm{NO}_{y}$ ratio values [Singh et al., 1986; Ridley et al., 1990]. The vertical distribution of the ratio $\mathrm{HNO}_{3} / \Sigma \mathrm{NO}_{y}$ showed that $\mathrm{HNO}_{3}$ composed on average $60 \%$ of $\Sigma \mathrm{NO}_{y y}$. The most significant deviation from this value occurred in stratospheric air masses, where the ratio was $\approx 90 \%$. These special cases are described below.
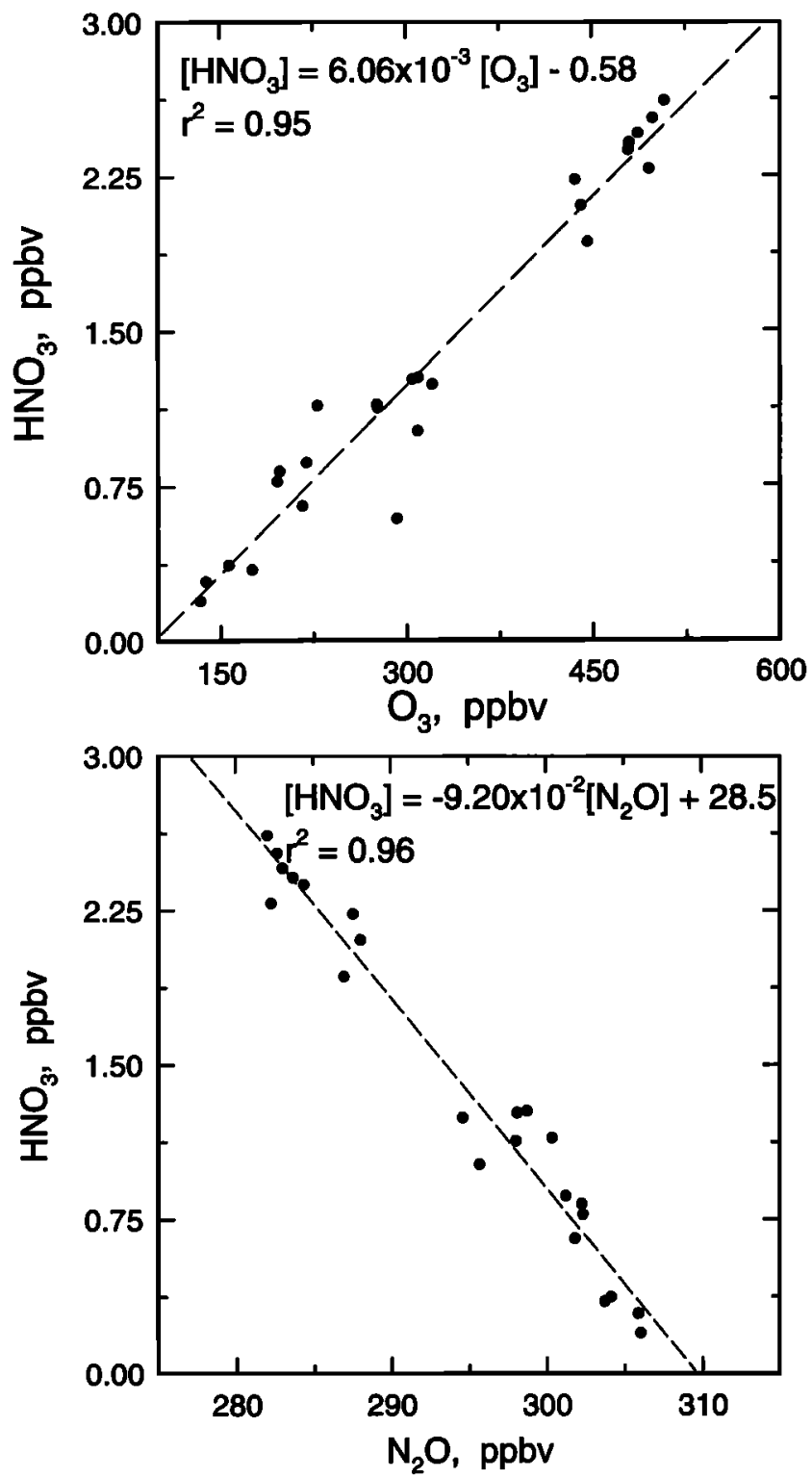

Figure 12. Relationships between $\mathrm{HNO}_{3}$ and $\mathrm{O}_{3}$ and $\mathrm{N}_{2} \mathrm{O}$ in stratospheric air masses sampled during three tropospheric folds ( $n$ $=25$ ) in the Pacific rim region. The ${ }^{7} \mathrm{Be}$ concentrations exceeded $1000 \mathrm{pCi} \mathrm{SCM}^{-1}$ during these events [Dibb et al., this issue].

\section{5. $\mathrm{HNO}_{3}$ in Stratospheric Air Masses}

On several occasions during PEM-West B the DC-8 encountered stratospherically influenced air masses. These events all occurred north of $20^{\circ} \mathrm{N}$ latitude [Dibb et al., this issue], with the most significant one at $11 \mathrm{~km}$ altitude over the Sea of Japan on March 11, 1995 (mission 17). This later event lasted nominally $90 \mathrm{~min}$, with peak $\mathrm{O}_{3}$ mixing ratios of 600 ppbv. Numerous acidic gas measurements and a 15-min period of standard additions for $\mathrm{HNO}_{3}$ were performed within this stratospheric air mass (data break around JD 70.075). These standard additions yield a mean recovery of $98 \pm 1 \%$ (see Figure 3a, at $11 \mathrm{~km}$ ), giving high confidence to the data obtained on this flight leg. Undoubtedly, the large ambient mixing ratios of $\mathrm{HNO}_{3}$ and the dry environmental conditions in this air mass facilitated the unity passing efficiency observed for our inlet assembly. In addition, $\mathrm{O}_{3}$ and $\mathrm{N}_{2} \mathrm{O}$, were constant $( \pm 5 \%)$ 
during this test interval, suggesting that the ambient $\mathrm{HNO}_{3}$ was also reasonably stable at $\approx 1200$ pptv.

Selected data obtained during this mission 17 flight leg are presented in Figure 11. The mixing ratio of $\mathrm{HNO}_{3}$ ranged from 750 to 2500 pptv. Coincident measurements of the carboxylic acids showed no detectable $\mathrm{HCOOH}$ but occasional trace amounts of $\mathrm{CH}_{3} \mathrm{COOH}$ ( $<30$ pptv) when $\mathrm{HNO}_{3}$ mixing ratios were $<1000$ pptv. To the best of our knowledge, these are among the first in situ measurements of $\mathrm{HNO}_{3}$ in the lower stratosphere.

There was good agreement between the general trends in the $\mathrm{HNO}_{3}$ mixing ratios and those of $\mathrm{O}_{3}$ and $\mathrm{N}_{2} \mathrm{O}$, that is, a positive correlation with $\mathrm{O}_{3}$ and a negative one with $\mathrm{N}_{2} \mathrm{O}$. Nitric acid also comprised the majority of $\Sigma \mathrm{NO}_{y}$, and the ratio $\mathrm{HNO}_{3} / \mathrm{O}_{3}$ closely mimicked the $\Sigma \mathrm{NO}_{y /} / \mathrm{O}_{3}$ relationship. The values observed for $\Sigma \mathrm{NO}_{\mathrm{yi}} / \mathrm{O}_{3}$ were, however, on the high side of those $(0.002-0.004)$ typically found in lower stratospheric air [Murphy et al., 1993].

To provide a more general picture of $\mathrm{HNO}_{3}$ relationships in the stratosphere, we show in Figure 12 a summary of its correlation with $\mathrm{O}_{3}$ and $\mathrm{N}_{2} \mathrm{O}$. The data plotted in Figure 12 reflect all measurements of $\mathrm{HNO}_{3}$ in stratospherically influenced air masses $(n=25)$ obtained during the PEM-West B expedition. It is evident from examination of Figure 12 that both of these correlations were linear and well defined $\left(r^{2} \geq 0.95\right)$. The slope of the relationship between $\mathrm{HNO}_{3}$ and $\mathrm{O}_{3}$ was $6.06 \times 10^{-3}$. This slope is essentially identical to the typical values of $\mathrm{NO}_{4} / \mathrm{O}_{3}\left(\approx 6 \times 10^{-3}\right)$ observed by Hübler et al. [1990] and lies in the middle of the $2-9 \times 10^{-3}$ range observed for $\mathrm{HNO}_{3} / \mathrm{O}_{3}$ by [Bregman et al., 1995]. For relationship between $\mathrm{HNO}_{3}$ and $\mathrm{N}_{2} \mathrm{O}$, we observed a slope of $-9.20 \times 10^{-2}$, which is similar to the seasonally averaged $\mathrm{NO}_{y} / \mathrm{N}_{2} \mathrm{O}$ slope of $-7.15 \times 10^{-2}$ found at $20-40^{\circ} \mathrm{N}$ latitude [Murphy and Fahey, 1994]. From the data presented by Bregman et al. [1995], we estimate a value of about $-8 \times 10^{-2}$ for $\mathrm{HNO}_{3} / \mathrm{N}_{2} \mathrm{O}$. Thus the first two sets of in situ $\mathrm{HNO}_{3}$ measurements in the lower stratosphere indicate that $\mathrm{HNO}_{3}$ may in some cases comprise a high percentage of $\mathrm{NO}_{y}(>90 \%)$ in these air masses. Overall, we found a value of $0.90 \pm 0.12(n=25)$ for the ratio $\mathrm{HNO}_{3} / \Sigma \mathrm{NO}_{y r}$. As pointed out by Bregman et al. [1995], the $\mathrm{HNO}_{3} / \mathrm{NO}_{y}$ ratio in the lower stratosphere is quite variable, some of which may be attributed to denitrification processes [Hübler et al., 1990]. It is clear that a much larger database is needed for stratospheric $\mathrm{HNO}_{3}, \mathrm{O}_{3}, \mathrm{~N}_{2} \mathrm{O}$, and $\mathrm{NO}_{y}$ to better define the interrelationships and understand the apparent year-to-year variations in them.

\section{Conclusions}

The large-scale distribution of acidic gases over the western Pacific basin shows that the largest mixing ratios occurred below 4 $\mathrm{km}$ altitude near the Asian continent in the latitude band of 5 $25^{\circ} \mathrm{N}$. Here discrete plumes were highly enriched in acidic gases and $\mathrm{CO}, \mathrm{C}_{2} \mathrm{H}_{2}, \mathrm{C}_{2} \mathrm{Cl}_{4}$, indicative of emission inputs from combustion and industrial sources. These general source influences were apparent up to $10 \mathrm{~km}$ altitude, but individual plumes were depleted in acidic gases above $6 \mathrm{~km}$. Scavenging of soluble species during vertical convective transport over the Asian continent is the most likely explanation. This same mechanism also appeared to be responsible for the vertical distribution of acidic gases during PEMWest A.

Below $6 \mathrm{~km}$ altitude, mixing ratios of $\mathrm{HCOOH}$ and $\mathrm{CH}_{3} \mathrm{COOH}$ were highly correlated $\left(r^{2}=0.87\right)$, with a slope characteristic of the nongrowing season at midlatitudes in the northem hemisphere. This same correlation was significantly poorer between 6 and $12 \mathrm{~km}$ altitude $\left(r^{2}=0.50\right)$, possibly reflecting the effects of transport through convective systems.
The partitioning of atmospheric nitrate favored $\mathrm{HNO}_{3}$ vapor over aerosol $\mathrm{NO}_{3}^{-}$, even in the marine boundary layer. The median value of the ratio was 2.5 below $6 \mathrm{~km}$ and 5.3 above this altitude. The largest ratio values were found directly in continental outflow plumes. Here mixing ratios of $\mathrm{HNO}_{3}$ were generally in the few ppbv range (up to 8), while those of aerosol $\mathrm{NO}_{3}^{-}$never exceeded 0.4 ppbv.

At latitudes $>20^{\circ} \mathrm{N}$, stratospheric air was sampled on several occasions. The largest event occurred at $11 \mathrm{~km}$ altitude over the Sea of Japan. Peak $\mathrm{O}_{3}$ mixing ratios were around $600 \mathrm{ppbv}$, while $\mathrm{HNO}_{3}$ approached $3 \mathrm{ppbv}$. Overall, we found linear relationships between $\mathrm{HNO}_{3}$ and $\mathrm{O}_{3}$ or $\mathrm{N}_{2} \mathrm{O}$ that yielded slopes of $6.06 \times 10^{-3}$ and $-9.20 \times$ $10^{-2}$, respectively, consistent with those previously reported for $\mathrm{NO}_{\boldsymbol{y}}$.

Acknowledgments. We appreciate the excellent support provided by the ground and flight crews of the NASA Ames DC-8 aircraft. The engineering support staff for the DC-8 is acknowledged in particular for their help in the design and fabrication of the diffusers and venturis used by the UNH and GIT instruments. The assistance of Faith Sheridan in the preparation of this manuscript is gratefully acknowledged. This research was supported by the NASA Global Tropospheric Chemistry program.

\section{References}

Arlander, D. W., D. R. Cronn, J. C. Farmer, F. A. Menzia, and H. H. Westberg, Gaseous oxygenated hydrocarbons in the remote marine troposphere, J. Geophys. Res., 95, 16,391-16,403, 1990.

Blake, D. R., T. -Y. Chen, T. W. Smith Jr., C. J. -L. Wang, O. W. Wingenter, F. S. Rowland, and E. W. Mayer, Three dimensional distribution of NMHCs and halocarbons over the northwestern Pacific during the 1991 Pacific Exploratory Mission (PEM-West A), J. Geophys. Res., 101, 17631778, 1996.

Blake, N. J., D. R. Blake, T.-Y Chen, J.E. Collins Jr., G.W. Sachse, B.E. Anderson, F. S. Rowland, Distribution and seasonality of selected hydrocarbons and halocarbons over the western Pacific basin during PEM-West A and PEM-West B, J. Geophys. Res., this issue.

Bregman, A., et al., Aircraft measurements of $\mathrm{O}_{3}, \mathrm{HNO}_{3}$, and $\mathrm{N}_{2} \mathrm{O}$ in the winter Arctic lower stratosphere during the Stratosphere-Troposphere Experiment by Aircraft Measurements (STREAM) 1, J. Geophys. Res., 100, 11,245-11, 260, 1995.

Crawford, J., et al., A photostationary state analysis of the $\mathrm{NO}_{2}$-NO system based on observations from the western and central North Pacific, $J$. Geophys. Res., 101, 2053-2072, 1996.

Dibb, J. E., R. W. Talbot, K. I. Klemm, G. L. Gregory, H. B. Singh, J. D. Bradshaw, and S. T. Sandholm, Asian influence over the western North Pacific during the fall season: Inferences from lead 210, soluble ionic specie,s and ozone, J. Geophys. Res., 101, 1779-1792, 1996.

Dibb, J. E., R. W. Talbot, B. L. Lefer, E. Scheuer, G. L. Gregory, E. V. Browell, J. D. Bradshaw, S. T. Sandholm, and H. B. Singh, Distributions of beryllium 7 and lead 210 over the western Pacific: PEM-West B, February - March 1994 J. Geophys. Res., this issue.

Duce, R. A., C. K. Unni, B. J. Ray, J. M. Prospero, and J. T. Merrill, Longrange atmospheric transport of soil dust from Asia to the tropical North Pacific: Temporal variability, Science, 209, 1522-1524, 1980.

Galasyn, J. F., K. L. Tschudy, and B. J. Huebert, Seasonal and diurnal variability of nitric acid vapor and ionic aerosol species in the remote free troposphere at Mauna Loa, Hawaii, J. Geophys. Res., 92, 3105-3113, 1987.

Gregory, G. L., A. S. Bachmeier, D. R. Blake, B. G. Heikes, D. C. Thomton, J. D. Bradshaw, and Y. Kondo, Chemical signatures of aged Pacific marine air: Mixed layer and free troposphere as measured during PEMWest A, J. Geophys. Res., 101, 1727-1742, 1996.

Heikes, B. G., Formaldehyde and hydroperoxides at Mauna Loa Observatory, J. Geophys. Res., 97, 18,001-18,013, 1992.

Hoell, J. M., D. D. Davis, S. C. Liu, R. Newell, H. Akimoto, R. J. McNeal, and R. J. Bendura, The Pacific Exploratory Mission-West, Phase B, J. Geophys. Res., this issue. 
Hübler, G., et al., Redistribution of reactive nitrogen in the lower Arctic stratosphere, Geophys. Res. Lett., 17, 453-456, 1990.

Huebert, B. J., Nitric acid and aerosol nitrate measurements in the equatorial Pacific region, Geophys. Res. Lett., 7, 325-328, 1980.

Huebert B. J., and A. L. Lazrus, Global tropospheric measurements of nitric acid vapor and particulate nitrate, Geophys. Res. Lett., 5, 577-580, 1978.

Huebert, B. J., and A. L. Lazrus, Tropospheric gas phase and particulate nitrate measurements, J. Geophys. Res., 85, 7322-7328, 1980.

Huebert, B. J., et al., Measurements of the nitric acid to $\mathrm{NO}_{x}$ ratio in the troposphere, J. Geophys. Res., 95, 10,193-10,198, 1990.

Lee, G., J. T. Merrill, and B. J. Huebert, Variation of free tropospheric total nitrate at Mauna Loa Observatory, Hawaii, J. Geophys. Res., 99, 12,821$12,831,1994$.

Merrill, J. T., Atmospheric long range transport to the Pacific Ocean, in Chemical Oceanography, edited by J. P. Riley and R. Duce, pp. 15-50, Academic, San Deigo, Calif., 1989.

Merrill, J. T., R. Newell, and S. Bachmeier, A meteorological overview for the Pacific Exploratory Mission - West, Phase B, J. Geophys. Res., this issue.

Murphy, D. M., and D. W. Fahey, An estimate of the flux of stratospheric reactive nitrogen and ozone into the troposphere, J. Geophys. Res., 99, 5325-5332, 1994.

Murphy, D. M., D. W. Fahey, M. H. Proffitt, S. C. Liu, K. R. Chan, C. S. Eubank, S. R. Kawa, and K. K. Kelly, Reactive nitrogen and its correiation with ozone in the lower stratosphere and upper troposphere, $J$. Geophys. Res., 98, 8751-8773, 1993.

Norton, R. B., Measurements of gas phase formic and acetic acids at the Mauna Loa Observatory, Hawaii, during the Mauna Loa Observatory photochemical experiment 1988, J. Geophys. Res., 97, 10,389-10,393, 1992.

Norton, R. B., M. A. Carroll, D. D. Montzka, G. Hübler, B. J. Huebert, G. Lee, W. W. Waren, B. A. Ridley, and J. G. Walega, Measurements of nitric acid and aerosol nitrate at the Mauna Loa Observatory during the Mauna Loa Observatory photochemical experiment 1988, J. Geophys. Res., 97, 10,415-10,425, 1992.

Prospero, J. M., D. L. Savoie, R. T. Nees, R. A. Duce, and J. Merrill, Particulate sulfate and nitrate in the boundary layer over the North Pacific Ocean, J. Geophys. Res., 90, 10,586-10,596, 1985.

Ridley, B., et al., Ratios of peroxyacetyl nitrate to active nitrogen observed during aircraft flights over the eastem Pacific Ocean and continental United States, J Geophys. Res., 95, 13,949-13,961, 1990.

Sandholm, S., J. Bradshaw, R. Talbot, H. Singh, G. Gregory, G. Sachse, and D. Blake, Comparison of $\mathrm{N}_{x} \mathrm{O}_{y}$ budgets from NASA's ABLE 3, PEWWest, and TRACE A measurement programs: An update, J. Geophys. Res., submitted, 1996 a.
Sandholm, S., S. Smyth, R. Bai, and J. Bradshaw, Recent and future improvements in two-photon LIF NO measurement capabilities, $J$. Geophys. Res., this issue.

Singh, H. B., and P. B. Zimmerman, Atmospheric distribution and sources of nonmethane hydrocarbons, in Gaseous Pollutants: Characterization and Cycling, John Wiley, New York, 1992.

Singh, H. B., L. J. Salas, and W. Viezee, Global distribution of peroxyacetyl nitrate, Nature, 32l, 588-591, 1986.

Talbot, R. W., K. M. Beecher, R. C. Harriss, and W. R. Cofer III, Atmospheric geochemistry of formic and acetic acids at a mid-latitude temperate site, J. Geophys. Res., 93, 1638-1652, 1988.

Talbot, R. W., A. S. Vijgen, and R. C. Harriss, Measuring tropospheric $\mathrm{HNO}_{3}$ : Problems and prospects for nylon filter and mist chamber techniques, J. Geophys. Res., 95, 7553-7561, 1990.

Talbot, R. W., B. W. Mosher, B. G. Heikes, D. J. Jacob, J. W. Munger, B. C. Daube, W. C. Keene, J. R. Maben, and R. S. Artz, Carboxylic acids in the rural continental atmosphere over the eastern United States during the Shenandoah Cloud and Photochemistry Experiment, J. Geophys. Res., 100, 9335-9343, 1995.

Talbot, R. W., et al., Chemical characteristics of continental outflow from Asia to the troposphere over the westem Pacific Ocean during SeptemberOctober 1991: Results from PEM-West A, J. Geophys. Res., 101, 1713$1725,1996$.

Talbot R. W., et al., Chemical characteristics of continental outflow from Asia to the troposphere over the western Pacific Ocean during FebruaryMarch 1994: Results from PEM-West B, J. Geophys. Res., this issue.

Wameck, P., Chemistry of the Natural Atmosphere, 757 pp., Academic, San Diego, Calif., 1988

Wunderli, S., and R. Gehrig, Influence of temperature on formation and stability of surface PAN and ozone: A 2-year field study in Switzerland, Atmos. Environ., 25, 1599-1608, 1991.

D.R. Blake and N.J. Blake, Department of Chemistry, University of California, Irvine, CA 92717.

J D. Bradshaw, S.T. Sandholm, and S. Smyth, School of Earth and Atmospheric Sciences, Georgia Institute of Technology, Atlanta, GA 30332. J.E. Collins, G.L. Gregory, and G.W. Sachse, NASA Langely Research Center, Hampton, VA 23665

J.E. Dibb, B.L. Lefer, E.M. Scheuer, and R.W Talbot, Institute for the Study of Earth, Oceans and Space, University of New Hampshire, Durham, NH 03824 (e-mail: rwt@christa.unh.edu)

(Received September 2, 1995; revised July 10, 1996; accepted July 28, 1996.) 